\title{
Distribution of pelagic Ostracoda (Crustacea) inhabiting the waters around Svalbard (Arctic Ocean: $\mathbf{7 6}^{\circ} 36-81^{\circ} 50 \mathrm{~N}$ )
}

\author{
Anna Baczewska $\cdot$ Katarzyna Blachowiak-Samolyk • \\ Martin V. Angel
}

Published online: 20 October 2011

(C) The Author(s) 2011. This article is published with open access at Springerlink.com

\begin{abstract}
Although, pelagic Ostracoda are locally abundant component of the mesozooplankton in the waters around Svalbard, the group remains poorly characterised both taxonomically and ecologically. Herein, the spatial and vertical variations in abundances and species composition of the pelagic Ostracoda assemblages are examined and related to the water masses. The study is based on a series of zooplankton samples collected with a multinet plankton sampler (MPS; HydroBios, Kiel), consisting of five nets fitted with a $180-\mu \mathrm{m}$ mesh net. Samples were collected from deep stations (i.e., with bottom depths $>300 \mathrm{~m}$ ) around Svalbard and included localities influenced by the West Spitsbergen Current and the East Spitsbergen Current and to the north of Svalbard, between years 2001 and 2006. Throughout all the samples studied Discoconchoecia elegans was the numerically dominant species. The other species found were Boroecia maxima, Boroecia borealis, Obtusoecia
\end{abstract}

Guest Editors: D. A. Do Carmo, R. L. Pinto \& K. Martens / Ostracoda - Biostratigraphy and Applied Ecology

A. Baczewska $(\bowtie) \cdot$ K. Blachowiak-Samolyk

Marine Ecology Department, Institute of Oceanology of Polish Academy of Sciences, Powstancow Warszawy 55, 81-712 Sopot, Poland

e-mail: abaczewska@iopan.gda.pl

M. V. Angel

National Oceanography Centre, Southampton SO14 3ZH, UK obtusata, and a rare novel Boroecia species. Analyses of the pelagic Ostracoda assemblages showed that their variability was predominantly influenced by four factors: water temperature, geographical position, bottom depth and season. The highest densities of D. elegans were correlated with salinities $>35$ PSU whereas $B$. maxima distribution was dependent on latitude. Highest concentrations of $B$. borealis were determined by longitude. Abundances of $O$. obtusata were positively correlated with warmer water temperatures. Thus this work suggests that halocyprids have the potential to be good indicators of environmental changes associated with shifts in climate at high latitudes in the North Atlantic.

Keywords Pelagic Ostracoda $\cdot$ Halocypridae Environmental factors · Horizontal and vertical distribution · Atlantic Waters

\section{Introduction}

Planktonic Ostracoda are a neglected component of mesoplanktonic communities, despite being almost ubiquitous throughout all depths of the world's oceans (Angel et al., 2007). They have received scant attention in studies of marine ecology because of identification problems, in spite of their relatively high abundances in oceans waters all over the world at all depths (Richter, 1994; Koppelmann \& Weikert, 1999). Pelagic Ostracoda play a significant role in 
open ocean pelagic ecosystems as detritivores (Angel, 1983a, b). Generally the knowledge of Ostracoda is poor even if they can contribute 4-5\% of total zooplankton abundances in the Nansen Basin (Mumm, 1993) and almost 4\% in zooplankton biomass of Makarov Basin (Kosobokova \& Hirche, 2000) and Arctic Canada Basin (Kosobokova \& Hopcroft, 2010). Richter (1994) reports that, in terms of their total abundance and biomass, the Ostracoda were ranked third in importance in the zooplankton of Greenland Sea.

Previously published accounts of pelagic Ostracoda in Arctic waters have been limited to comments in papers concerning general descriptions of the zooplankton (Kielhorn, 1952; Wiborg, 1955; Williams, 1975; Kosobokova, 1982; Hanssen, 1997; WeigmannHaass, 1997; Blachowiak-Samolyk et al., 2008; Kosobokova \& Hopcroft, 2010).

The earliest publication dealing with pelagic Ostracoda in the Northern Hemisphere was written by Sars (1865), who described three halocyprid species from Norwegian coastal waters. Further taxonomical studies were performed by Brady \& Norman (1896), Claus (1890), Müller (1906) and Skogsberg (1920). Poulsen's Dana reports $(1973,1977)$ helped to summarise and extend the existing knowledge about the zoogeography of halocyprids, but they did not cover the Arctic. Recently Chavtur \& Bashmanov (2007), and Bashmanov \& Chavtur (2008, 2009) have published papers detailing the zoogeographical distributions of halocyprids and myodocopids in the Arctic and have greatly improved morphological descriptions of the dominant species together with data on their vertical distributions. Arctic studies by Russian oceanographers presenting the results from comprehensive sampling programmes conducted throughout the 20th century have focused on taxonomical descriptions of individual species (Chavtur \& Bashmanov, 2007; Bashmanov \& Chavtur, 2008, 2009) and their Arctic-wide distributions.

However, despite their importance in pelagic assemblages, few papers have dealt with the distributions and diversity of pelagic Ostracoda in the Arctic.

The objective of this investigation is to describe distribution and biodiversity of pelagic Ostracods around Svalbard basing on extensive grid of deep water zooplankton samples collected in 2001-2006. All aspects of the ecology of zooplankton assemblages in the highly productive waters around Svalbard are of particular current interest in relation to the responses of the Arctic ecosystem to global climate change. This study correlates data on Ostracoda from different regions of Fram Strait, Barents Sea and west and north of Svalbard waters with the different hydrographic regimes and vertical stratification.

This paper also summarises existing knowledge of Arctic halocyprids spatial distribution and identify the environmental factors determining these distributions and also highlights some critical taxonomical problems within the group.

\section{Materials and methods}

Study area

The region studied is strongly influenced by the West Spitsbergen Current (WSC) which advects large amounts (75\%) (Piechura et al., 2001) of relatively warm, saline and nutrient-rich Atlantic Water (AtW) into the Arctic Basin through Fram Strait-the deepest and the most important connection between Nordic Seas and Arctic Basin (Loeng, 1991). The other important current is East Spitsbergen Current (ESC), that advects cold polar waters southwards around the East coast of Svalbard. Mixing between these two water masses results in strong gradients of salinity and temperature (Svendsen et al., 2002). Other physical processes that strongly influence the hydrography of the Svalbard region include evaporation and ice melting.

Oceanographic conditions

Profiles of temperature, salinity and density were measured vertically at each sampled station using a Sea-Bird Electronics SBE 911+ CTD sonde throughout the total water column. Water masses have been defined based on the criteria of Loeng (1991), Piechura et al. (2001), Svendsen et al. (2002), and Cottier et al. (2005) (presented in Table 1). The designated water masses were Atlantic Water (AtW), Surface Water (SW), Mixed Water (MW), Arctic Water (ArW), Arctic Deep Water (ArDW), Mixed Fram Strait Water (MFSW) and Mixed Barents Water (MBW) (Fig. 1). 
Table 1 Water mass classification in the area sampled around Svalbard based on temperature and salinity (see Loeng, 1991; Piechura et al., 2001; Svendsen et al., 2002; Cottier et al., 2005)

\begin{tabular}{|c|c|c|c|}
\hline Water masses & ID & $\begin{array}{l}\text { Temperature } \\
\left({ }^{\circ} \mathrm{C}\right)\end{array}$ & $\begin{array}{l}\text { Salinity } \\
\text { (PSU) }\end{array}$ \\
\hline Atlantic Water & AtW & $2-7$ & $>34.8$ \\
\hline Surface Water & SW & $1-5$ & $32.0-34.3$ \\
\hline Melted Water & MW & $<1$ & $<34.3$ \\
\hline Arctic Water & ArW & -1.9 to 1 & $34.4-34.8$ \\
\hline Arctic Deep Water & ArDW & -1 to 2 & $>34.8$ \\
\hline Mixed Fram Strait Water & MFSW & $>1.0$ & $34.3-34.8$ \\
\hline Mixed Barents Sea Water & MBW & -1.9 to 1 & $<34.0$ \\
\hline
\end{tabular}

\section{Zooplankton sampling}

The samples were collected during several Norwegian and Polish programmes: On Thin Ice (OTI), CABANERA, UV Project, and also during oceanographic cruises conducted by the Norwegian Polar Institute (NPI), the Institute of Oceanology Polish Academy of Sciences (IOPAS) and the University Centre in Svalbard (UNIS). Zooplankton and the oceanographic parameters were collected from the research vessels Lance, Jan Mayen and Oceania between 31.07.2001 and 07.09.2006 in Spring, Summer and Autumn. Detailed data on the geographical coordinates of sampling stations and bottom depths are presented in Table 2. The springtime sampling was carried out at Norskebanken (stations 411 and 441), and in the Fram Strait (station 419) and one station on the continental shelf (station V6). Summer samples were collected from the continental slope (station V6-04), Hornsund Banken (stations H5-01, H5-02, H5-03) and Erik Eriksen Strait (stations XI-D and XI-N), Autumn surveys were conducted at Norskebanken (stations N2, N3) Sofiadjupet (stations ICE 3-D, ICE 3-N), on the slope of Flaket (station FL) and the west shelf of Svalbard (stations V6-U, V6-1, Ch2-U and D12-U). Area investigated covered the region between: $76.22^{\circ}-80.30^{\circ} \mathrm{N}$ and $4.32^{\circ}-$ $30.02^{\circ} \mathrm{E}$ (Table 2; Fig. 2 ).

Zooplankton samples were collected using a multinet plankton sampler (MPS; HydroBios, Kiel), consisting of five automatically closing nets with a square $0.25 \mathrm{~m}^{2}$ mouth and fitted with a $180-\mu \mathrm{m}$ mesh net. At stations with sampling depths $<600 \mathrm{~m}$ five standard depth strata were sampled as follows: 0-20,
20-50, 50-100, 100-200 and 200-bottom (Table 2). At stations where the sampling depths were $>600 \mathrm{~m}$ the standard depth strata of samples were 0-20, 20-50, 50-200, 200-600 and 600-bottom (Table 2). At station $\mathrm{H} 5$, the depth strata sampled were modified according to the observed depths of the thermocline and halocline. At stations V6-1 and V6-St the sampling strategy were modified to $0-120$, 120-200, 200-600, 600-900 and 900-1100 m (Table 2).

In this study the vertical structuring has been simplified by categorising the data into three depth classes: surface $(0-200 \mathrm{~m})$, mid (200-bottom at shallow stations, and $200-600 \mathrm{~m}$ at deep stations) and deep (600-bottom). Results from all layers, where Ostracoda were observed, were included in statistical analyses.

Zooplankton samples were preserved immediately after collection in $4 \%$ formaldehyde solution in seawater buffered with borax. All Ostracoda specimens were later picked out from the total zooplankton samples and identified under a stereomicroscope with maximum magnification $\times 56$, and fitted with a micrometer eye-piece. Identifications were performed according to procedures developed in earlier studies dealing with pelagic Ostracoda (Iles, 1953; Angel, 1968, 1993; Chavtur, 1977; Blachowiak-Samolyk, 1999; Angel \& Blachowiak-Samolyk, 2006).

The specific identification of all the Ostracoda species and their developmental stages can be achieved visually and by length measurements, but requires confirmation by detailed qualitative analyses based on morphometrical characters (carapace shape, location of the asymmetrical glands and frontal organ structure). Numerous dissections were made to confirm the identifications.

\section{Statistical analyses}

To study relationship between abiotic environmental variables: temperature, longitude, latitude, bottom depth, season (Spring, Summer and Autumn), salinity and layer depths on the Ostracoda assemblages, redundancy analysis (RDA) in CANOCO for Windows v.4.5 package (Braak \& Smilauer, 2002) was used. Season was expressed as a dummy variable (e.g., samples collected during Spring were attributed with a value 'one', whereas the other seasons (Summer and 


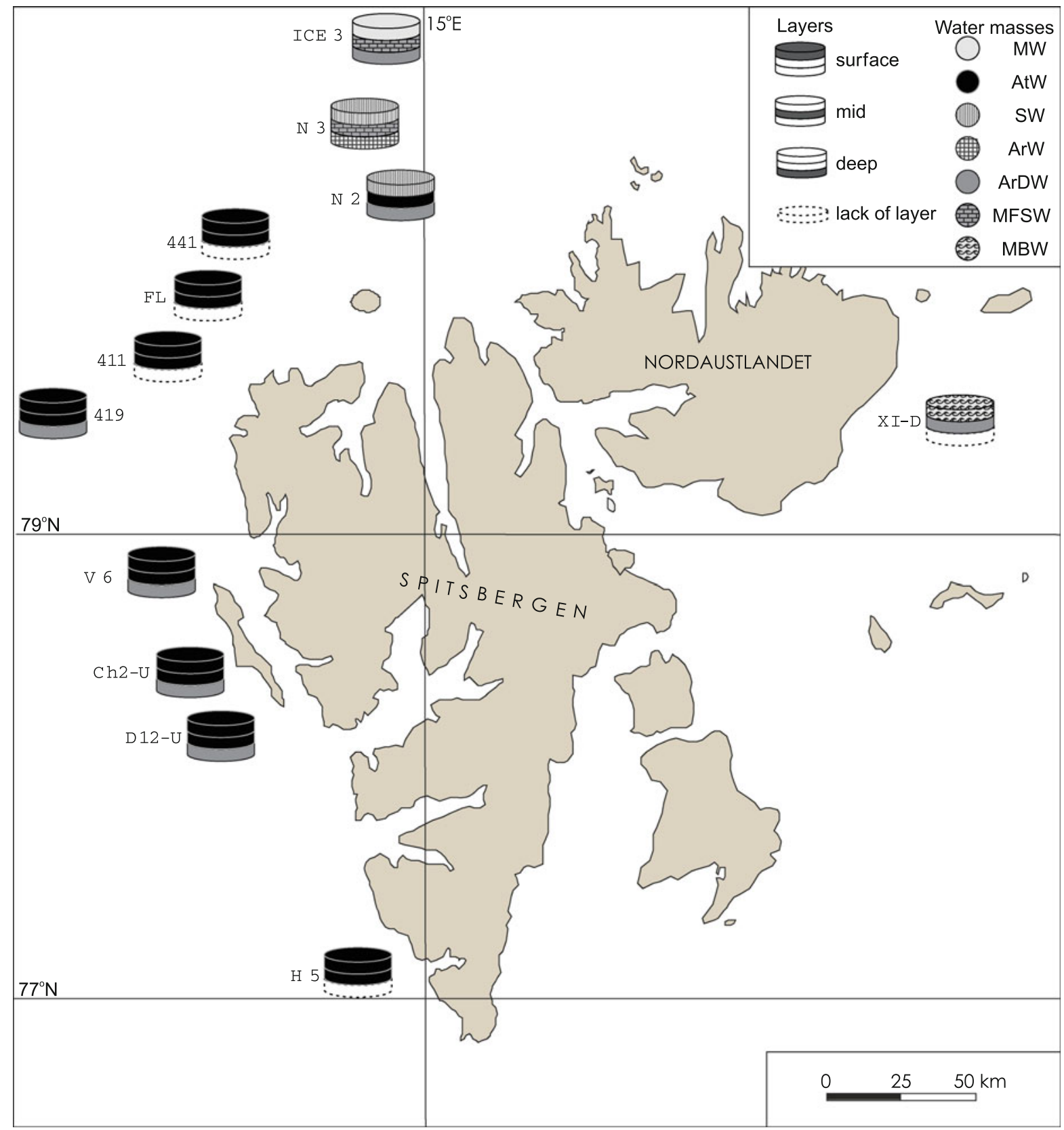

Fig. 1 Water masses determined from CTD tows in the Svalbard waters simplified for the purpose of this paper. Water masses defined in Table 1. Three depth categories were established as before. Results from stations V6 (V6-U, V6-1,

Autumn) were attributed with 'zeros'; for the other environmental variables (i.e., temperature, salinity or bottom depth) the observed mean values for each sampled stratum were used.
V6-St, V6-04), H5 (H5-01, H5-02, H5-03), ICE 3 (ICE 3-N, ICE $3-\mathrm{D}), \mathrm{XI}$ (XI-D, XI-N) were averaged to simplify the view of results, which did not cause any significant changes to the figures

Vertical and horizontal gradients in pelagic Ostracoda abundance were standardised to ind. $1000 \mathrm{~m}^{-3}$ for all sampled depth categories, at which 1 or more individuals were found. The abundance data were $\log$ 
Table 2 Stations ID, sampling areas, project name, dates, geographical positions (latitude and longitude) and bottom depth in the Svalbard waters

\begin{tabular}{|c|c|c|c|c|c|c|}
\hline Station ID & Sampling area & Project & Date & $\begin{array}{l}\text { Latitude } \\
\left({ }^{\circ} \mathrm{N}\right)\end{array}$ & $\begin{array}{l}\text { Longitude } \\
\left({ }^{\circ} \mathrm{E}\right)\end{array}$ & $\begin{array}{l}\text { Bottom } \\
\text { depth }(\mathrm{m})\end{array}$ \\
\hline ICE 3-D & Sofiadjupet & On Thin Ice & 01.09.2003 & 80.30 & 12.29 & 1600 \\
\hline ICE 3-N & Sofiadjupet & On Thin Ice & 01.09 .2003 & 80.30 & 12.29 & 1600 \\
\hline $\mathrm{N} 2$ & Norskebanken & On Thin Ice & 14.08 .2003 & 80.19 & 12.00 & 775 \\
\hline N3 & Norskebanken & On Thin Ice & 14.08.2003 & 80.25 & 12.01 & 1120 \\
\hline FL & Fram Strait & On Thin Ice & 13.08 .2003 & 80.04 & 8.28 & 500 \\
\hline 411 & Fram Strait & On Thin Ice & 17.05.2003 & 79.28 & 9.28 & 400 \\
\hline 419 & Fram Strait & On Thin Ice & 19.05.2003 & 79.20 & 4.32 & 1200 \\
\hline 441 & Fram Strait & On Thin Ice & 21.05.2003 & 80.04 & 8.31 & 483 \\
\hline D12-U & Continental shelf & UNIS & 07.09.2006 & 78.08 & 08.32 & 1185 \\
\hline Ch2-U & Continental shelf & UNIS & 27.08.2006 & 78.16 & 08.26 & 1300 \\
\hline V6-U & Continental shelf & UNIS & 27.08.2006 & 78.32 & 07.25 & 1100 \\
\hline V6-1 & Continental shelf & NPI & 21.09.2002 & 78.32 & 07.25 & 1100 \\
\hline V6-St & Continental shelf & UV Project & 17.04.2002 & 78.32 & 07.25 & 1100 \\
\hline V6-04 & Continental shelf & UV Project & 08.06 .2004 & 78.32 & 07.25 & 1100 \\
\hline H5-01 & Hornsund & IOPAN & 31.07.2001 & 76.22 & 12.31 & 500 \\
\hline $\mathrm{H} 5-02$ & Hornsund & IOPAN & 27.07.2002 & 76.22 & 12.31 & 500 \\
\hline H5-03 & Hornsund & IOPAN & 29.07.2003 & 76.22 & 12.31 & 500 \\
\hline XI-D & Erik Eriksen Strait & Cabanera & 30.07 .2004 & 79.50 & 30.02 & 220 \\
\hline XI-N & Erik Eriksen Strait & Cabanera & 30.07 .2004 & 79.50 & 30.02 & 220 \\
\hline
\end{tabular}

transformed $\left(x^{\prime}=\log (10 x+1)\right)$ and environmental variables were ranked according to their quantitative importance by forward selection using a Monte Carlo permutation test (Braak \& Smilauer, 2002).

Correlation analyses (Species Response Curves) between selected environmental key driving parameters (salinity, temperature and depth layer) with the strongest influence $(P<0.05)$ on four most frequent Ostracoda species (D. elegans, B. maxima, B. borealis and $O$. obtusata) distribution were performed (Braak \& Smilauer, 2002).

\section{Results}

Hydrology

Along and near the shelf slope of Fram Strait AtW was predominant in the surface and at mid-layers (is specified in "Materials and methods" section). ArDW was present in the deepest layer at station 419 (Fig. 1). In the surface layers strong influence of SW was observed at stations from Sofjadjupet to Norskebanken (N2, N3, ICE 3) and MW at station ICE 3. MFSW occurred in mid-layers at stations N3 and ICE 3, but was replaced by AtW at station N2. In the deep layer ArDW was recorded at stations N2 and ICE 3, and ArW occurred at station N3 (Fig. 1).

At station V6 the hydrographic structure was characterised by ArW at the surface and mid-layers, and ArDW >600 m. A similar hydrographic structure was observed at stations Ch2-U and D12-U and at station H5 where AtW appeared in both surface and mid-layers during all three sampling years (Fig. 1).

At the only station from Barents Sea (XI), MBW occurred in the surface layer, with ArDW in the midlayer (Fig. 1).

Ostracoda assemblages-species composition and abundances

A total of 3619 individuals of pelagic Ostracoda were picked out and five species were identified. Four of these species, namely Discoconchoecia elegans (Sars, 1865), Boroecia maxima (Brady \& Norman, 1896), Boroecia borealis (Sars, 1865) and Obtusoecia obtusata (Sars, 1865) had been recorded previously from the region. The fifth species, very similar to B. maxima 


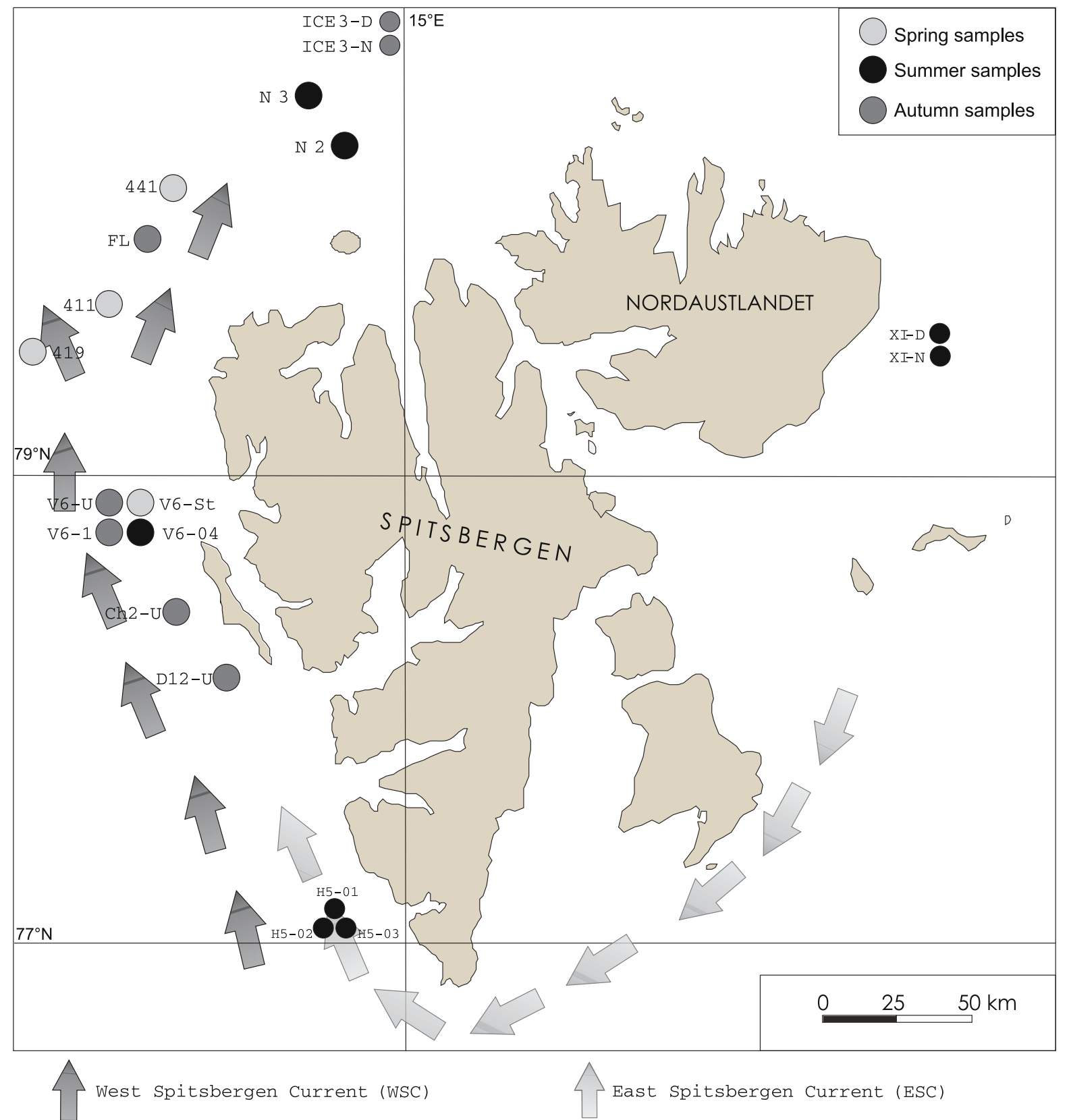

Fig. 2 Sampling area in Svalbard waters in Spring, Summer and Autumn in years 2001-2006

but smaller, is novel to science (Angel \& Baczewska, in prep.). However, the adult female examined has a short straight fused frontal organ, which is shorter than the limb of the first antenna and the capitulum ends in a long, tip point. This combination of characters suggests that the species may belong to a novel genus.

Throughout, the mean abundance of the pelagic Ostracoda was 724 ind. $\mathrm{m}^{-2}$ (Fig. 3). The lowest abundance of 83 ind. $\mathrm{m}^{-2}$ was observed at the Barents Sea (station XI), and abundances were relatively low $\left(\sim 600\right.$ ind. $\left.\mathrm{m}^{-2}\right)$ at the group of stations situated over the continental slope of the Fram Strait and western Spitsbergen (stations: 441, 411, N3, FL, V6-U, V6-St and Ch2-U) (Fig. 3). Moderate Ostracoda abundances (600-1800 ind. $\mathrm{m}^{-2}$ ) were observed at some of the northern stations 
(ICE 3 and N2), and western (stations V6-04, V6-1 and D12-U) (Fig. 3). The highest abundance of Ostracoda was recorded at the Fram Strait station 419 (2080 ind. $\mathrm{m}^{-2}$ ).

The most abundant species was $D$. elegans, which contributed $48 \%$ of the total Ostracoda compared with B. maxima $36 \%, B$. borealis $12 \%$ and $O$. obtusata $4 \%$. The novel species was very rare $0.19 \%$. Discoconchoecia elegans occurred at station H5, where it made up $75 \%$ of the Ostracoda assemblage and it was also dominant at the stations: D12-U, FL and N2 but its dominance declined northwards, to $42 \%$ at station V6 where it was replaced as the dominant Ostracoda species by $B$. maxima (56\%), whose share increased further to $86 \%$ at the station N3. The contribution of the third most abundant species-B. borealis-ranged from $3 \%$ at the station $\mathrm{Ch} 2-\mathrm{U}$ to $20 \%$ at the station 441 , but at station XI it became the dominant species (67\%). The share of $O$. obtusata was generally small, ranging from $1 \%$ at stations D12-U, Ch2-U, and 419 to $6 \%$ at station H5-but its contribution increased sharply to $20 \%$ at the station FL.

Ostracoda distributions - vertical gradients

Analysis of vertical distributions has been simplified by considering the data into three categories: surface (0-200 m), mid-layer (200-bottom at shallow stations, and 200-600 $\mathrm{m}$ at deep stations) and deep layer (600-bottom) (Fig. 4A-D).

The highest abundances of D. elegans were found at stations N2 (1750 ind. $1000 \mathrm{~m}^{-3}$ ) and H5 (2200 ind. $1000 \mathrm{~m}^{-3}$ ) in the mid-layer (Fig. 4A), whereas its lowest numbers were observed at stations ICE 3, N3 and $411\left(<500\right.$ ind. $\left.1000 \mathrm{~m}^{-3}\right)$ in the surface layer. Deep layers at stations 419 and V6 were characterised by the highest abundance of $B$. maxima (1550 ind. $1000 \mathrm{~m}^{-3}$ and 950 ind. $1000 \mathrm{~m}^{-3}$, respectively) and at almost all analysed stations this species concentrated within this depth range (Fig. 4B). The highest numbers of $B$. borealis were found in the mid-layer at station ICE 3 (760 ind. $1000 \mathrm{~m}^{-3}$ ), and it was also abundant in the mid-layer at stations N2, 441, 411, 419, V6 and XI (>200 ind. $1000 \mathrm{~m}^{-3}$ ) (Fig. 4C). The highest concentrations of $O$. obtusata were found in the surface layer at station FL (340 ind. $1000 \mathrm{~m}^{-3}$ ), and at stations $\mathrm{H} 5$ and N2 (>110 ind. $\mathrm{m}^{-3}$ ) (Fig. 4D). The novel Boroecia species was found only in the deep layers at four stations (H5, V6, Ch2-U and D12-U), in abundances that ranged from 6 to 24 ind. $1000 \mathrm{~m}^{-3}$ (data not shown).

Svalbard Ostracods distribution and its controlling factors

Evident regularities were revealed in the RDA analyses based on vertical abundances (ind. $1000 \mathrm{~m}^{-3}$ ) (Fig. 5). The variables tested (temperature, longitude, latitude, bottom depth, seasons, salinity and layer depth) together explained 53\% of a total variability in the Ostracoda distribution (Table 3).

Temperature emerged as the most influential parameter in the RDA analyses, explaining $23 \%$ of the variability in the overall abundances. There was a close relationship between temperature and higher abundance of $O$. obtusata and D. elegans (Fig. 5; Table 3). Higher abundances of B. borealis and $D$. elegans were correlated with longitude, which explained $12 \%$ of the overall Ostracoda variability.

Latitude and bottom depth explained $4 \%$ of the total Ostracoda variability with season (Spring and Autumn) accounting for $3 \%$, and salinity $2 \%$. Surprisingly layer depth and the third season (Summer), contributed weakly to the model, explaining only $1 \%$ of the overall variability and in the analyses had an insignificant effect on the Ostracoda distributions.

Species Response Curves showed a clear relationship between the most abundant Ostracoda species and various environmental variables plotted against them. Salinity had the strongest influence on D. elegans distribution $(P=0.0021) \quad$ (Fig. 6A). Decreasing abundances of $B$. maxima were associated with temperature drop $(P=0.000016)$ (Fig. 6B). The $B$. borealis highest concentrations positively correlated with salinity increase $(P=0.021)$ (Fig. 6C), whereas $O$. obtusata abundances declined with increasing depth $(P=0.000454)$ (Fig. 6D).

\section{Discussion}

Species composition and abundances

Pelagic Ostracoda are poorly known component of high latitude zooplankton communities in the Arctic but very important component in terms of both their biomass and abundance (Hirche et al., 1991; 


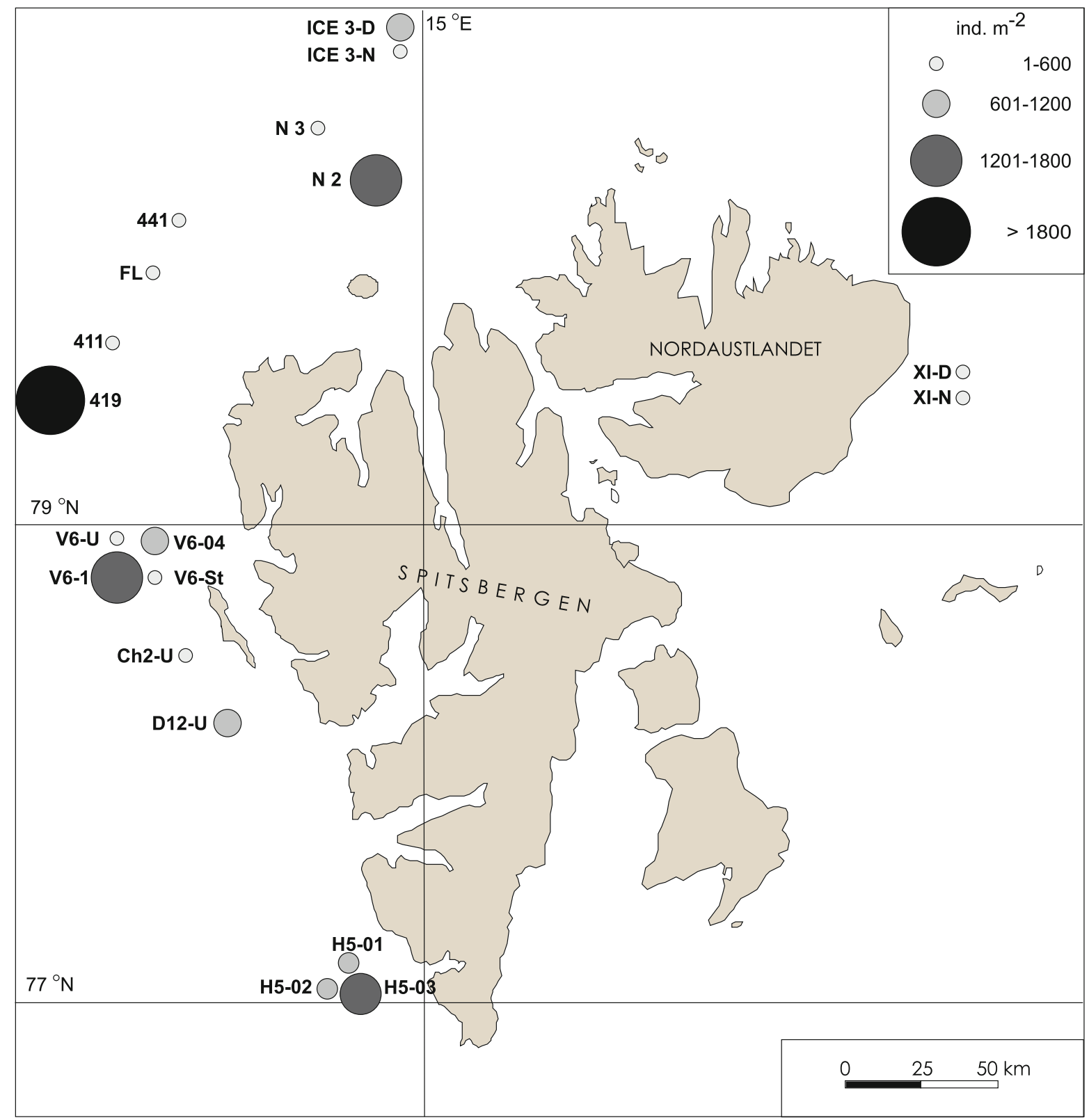

Fig. 3 Horizontal abundances (ind. $\mathrm{m}^{-2}$ ) of pelagic Ostracoda in Svalbard waters

Kosobokova \& Hirche, 2000; Blachowiak-Samolyk \& Angel, 2007).

This study shows that D. elegans is numerically dominant species in Svalbard waters. It was one of the first halocyprids described (Sars, 1865) from high latitudes in the Atlantic from the Lofoten Islands (north-western Norway). Since then it has been the most frequently recorded species of halocyprid Ostracoda (e.g., Müller, 1906; Skogsberg, 1920; Deevey,
1968; Poulsen, 1973; Angel, 1977a, b; Martens, 1979; Angel et al., 2007). Published reports show it has a cosmopolitan distribution, but populations from different regions have widely differing size ranges (e.g., Skogsberg, 1920; Deevey, 1968; Mumm, 1991). Preliminary results of molecular sequencing of the $\mathrm{CO} 1$ gene in halocyprids have shown that whenever adult populations of similar looking species, but with different mean carapace lengths, are analysed, they 


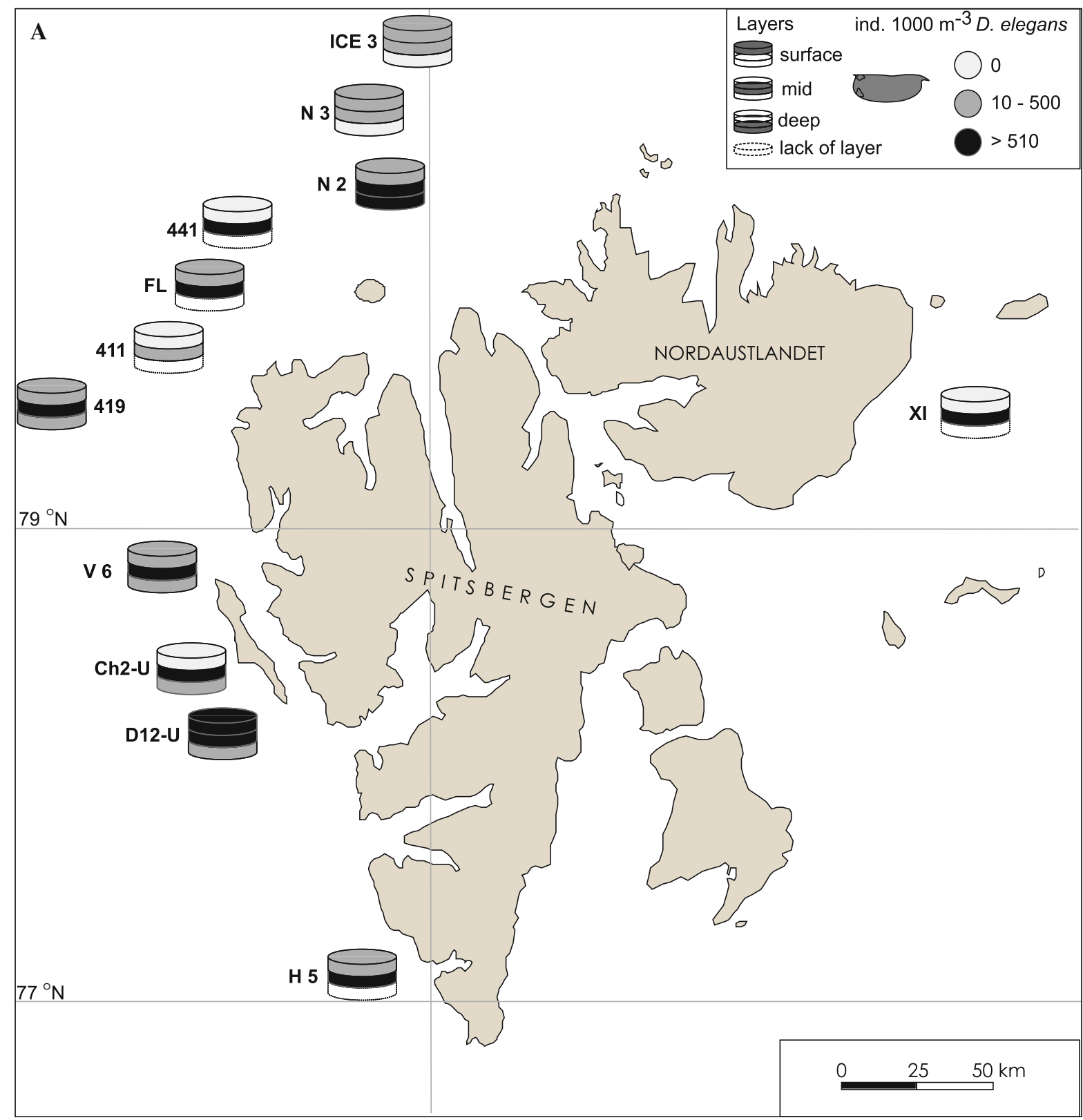

Fig. 4 Vertical distributions of species (ind. $\left.1000 \mathrm{~m}^{-3}\right)$ in the three depth categories: surface (0-200 m), mid (200-bottom at shallow stations, and 200-600 m at deep stations) and deep (600-bottom). A D. elegans, B B. maxima, C B. borealis, D O. obtusata

have proved to be separate species (Nigro, personal communication). In the material collected close to Svalbard, two distinct size ranges of adult D. elegans occurred [o: $1.70-2.13 \mathrm{~mm}$ and $2.19-2.35 \mathrm{~mm}$; o: $1.80-2.20 \mathrm{~mm}$ and 2.30-2.80]; the smaller forms are typical of sizes found at latitudes of $60^{\circ}-70^{\circ} \mathrm{N}$ in the North Atlantic and the large form occurs in high latitudes in the Arctic (unpublished data), and these two forms are almost certainly separate species. In Svalbard waters the smaller form of D. elegans constituted almost a half of all recorded Ostracoda (48\%), with mean abundance 350 ind. $\mathrm{m}^{-2}$, whereas in the Nansen Basin, Mumm (1991) reported it as contributing $20 \%$ of the Ostracoda assemblages with average concentration of 160 ind. $\mathrm{m}^{-2}$. Bashmanov \& Chavtur (2009) also reported the contribution of $D$. 


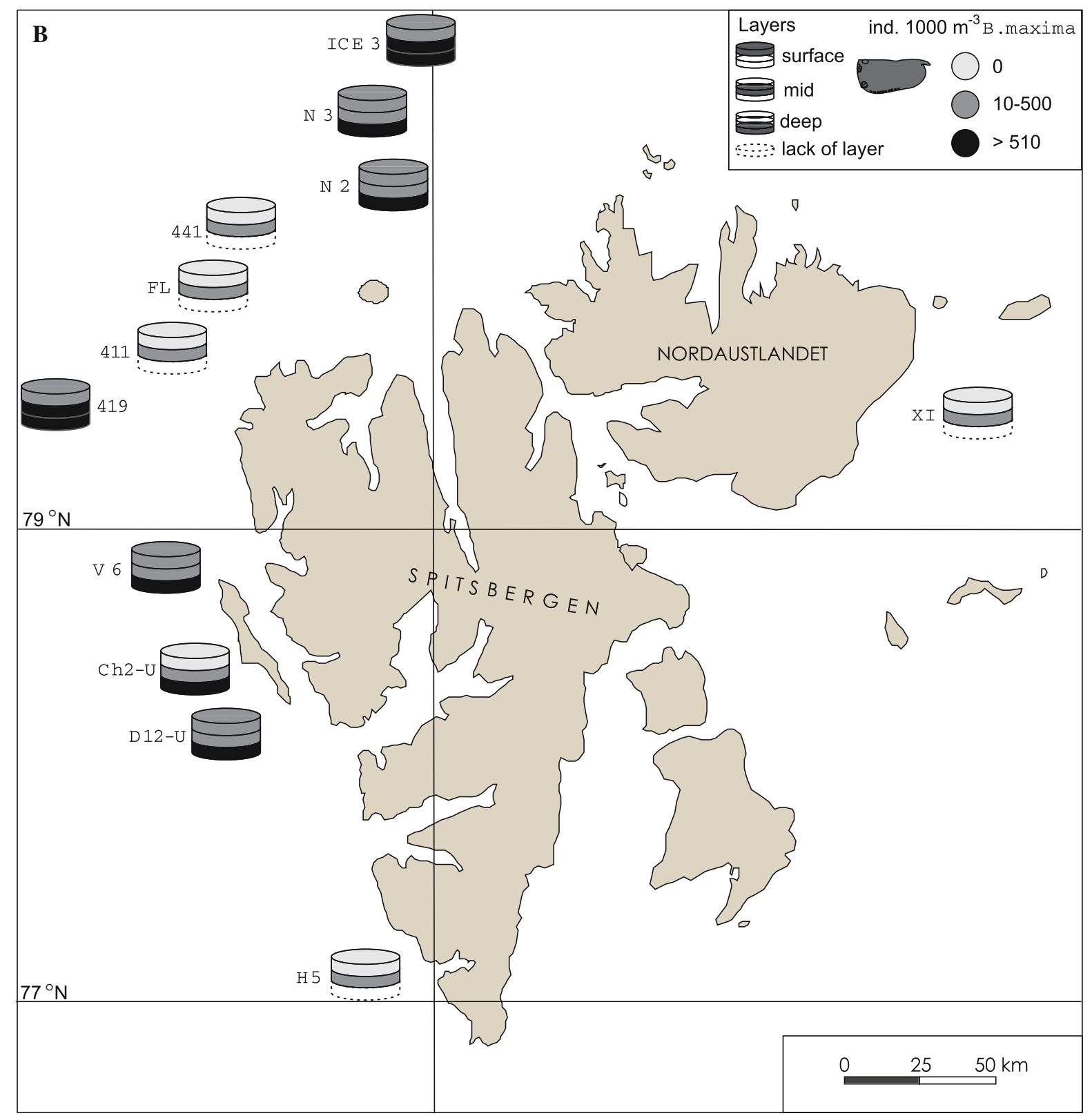

Fig. 4 continued

elegans to the overall Ostracoda concentrations range from $10 \%$ in the Russian part of Arctic Basin to $26 \%$ near Svalbard, but raised to $28-65 \%$ near Franz Josef Land.

Boroecia maxima was the second most abundant halocyprid species (36\%) and the biggest one (ㅇ: 3.30-3.85 mm; ô: $3.10-3.30 \mathrm{~mm}$ ). This species was originally described from the Greenland Sea $\left(74^{\circ} \mathrm{N}\right)$ and the Faroe Channel $\left(\sim 60^{\circ} \mathrm{N}\right)$ (Brady \& Norman, 1896). But was incorrectly synonymised with B. borealis by Müller (1906) and Skogsberg (1920) despite its much larger size and lack of shoulder vaults. Consequently, B. maxima has constantly been overlooked in subsequent studies, making comparative analyses of records of Boroecia species difficult. For example, Richter (1994) in his 


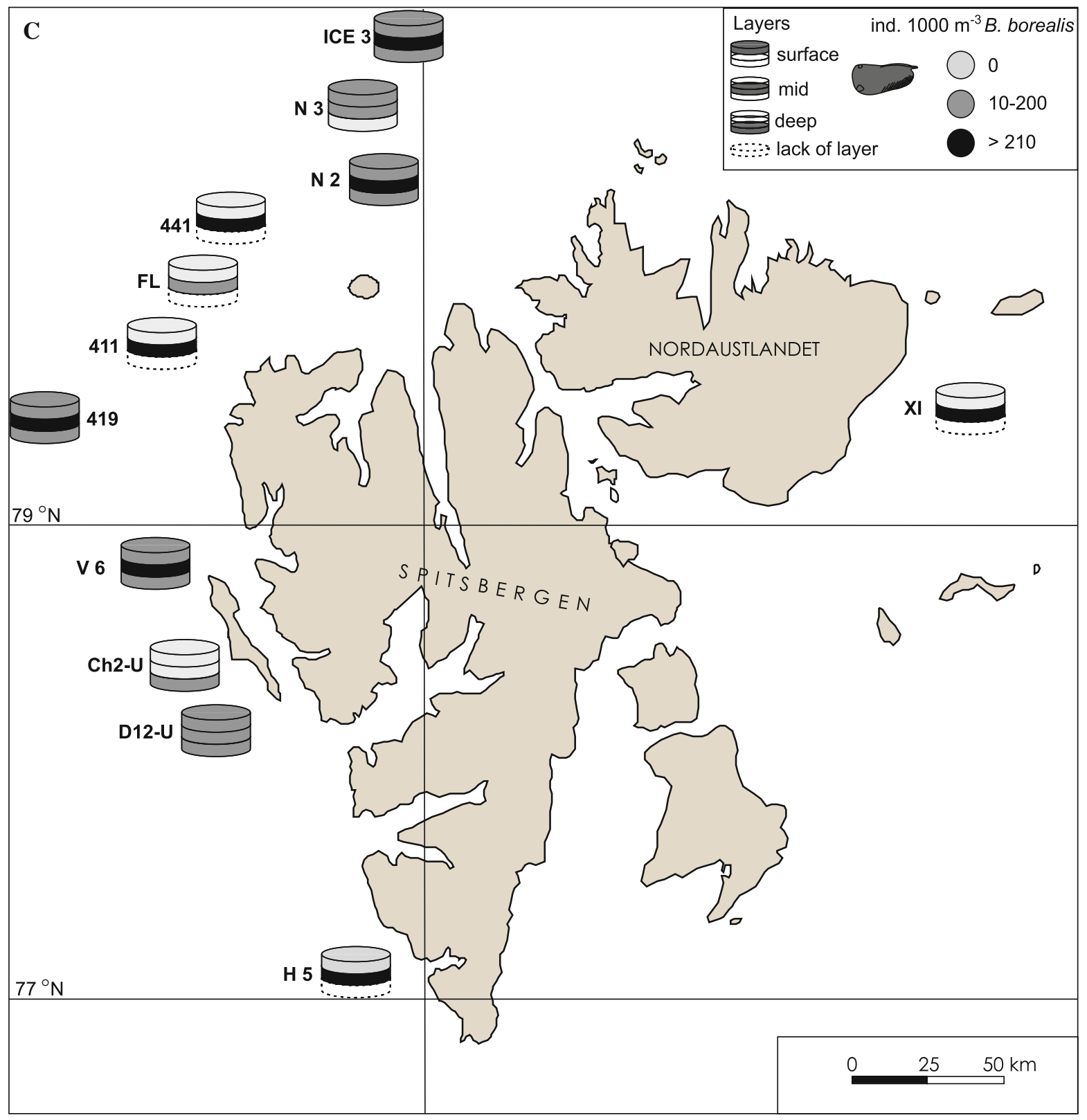

Fig. 4 continued

comprehensive and detailed study of halocyprids from the Greenland Sea gives size data that implies that the majority (but not all) of his specimens were $B$. maxima, although he identified them all as B. borealis. Recent sampling in the Canadian Deep to the north of the Bering Strait (Kosobokova \& Hopcroft, 2010) as well as in whole Central Arctic (Bashmanov \& Chavtur, 2009) have shown
B. maxima to be by far most dominant halocyprid species. This high Arctic species has been described as dominating in halocyprid populations off Svalbard (Poulsen, 1977).

Boroecia borealis (ㅇ: $2.30-2.72 \mathrm{~mm}$, ô: $2.02-$ $2.50 \mathrm{~mm}$ ) was also originally described by Sars (1865) from off the Lofoten Islands (Norwegian Sea). It is abundant and often dominant in the North 


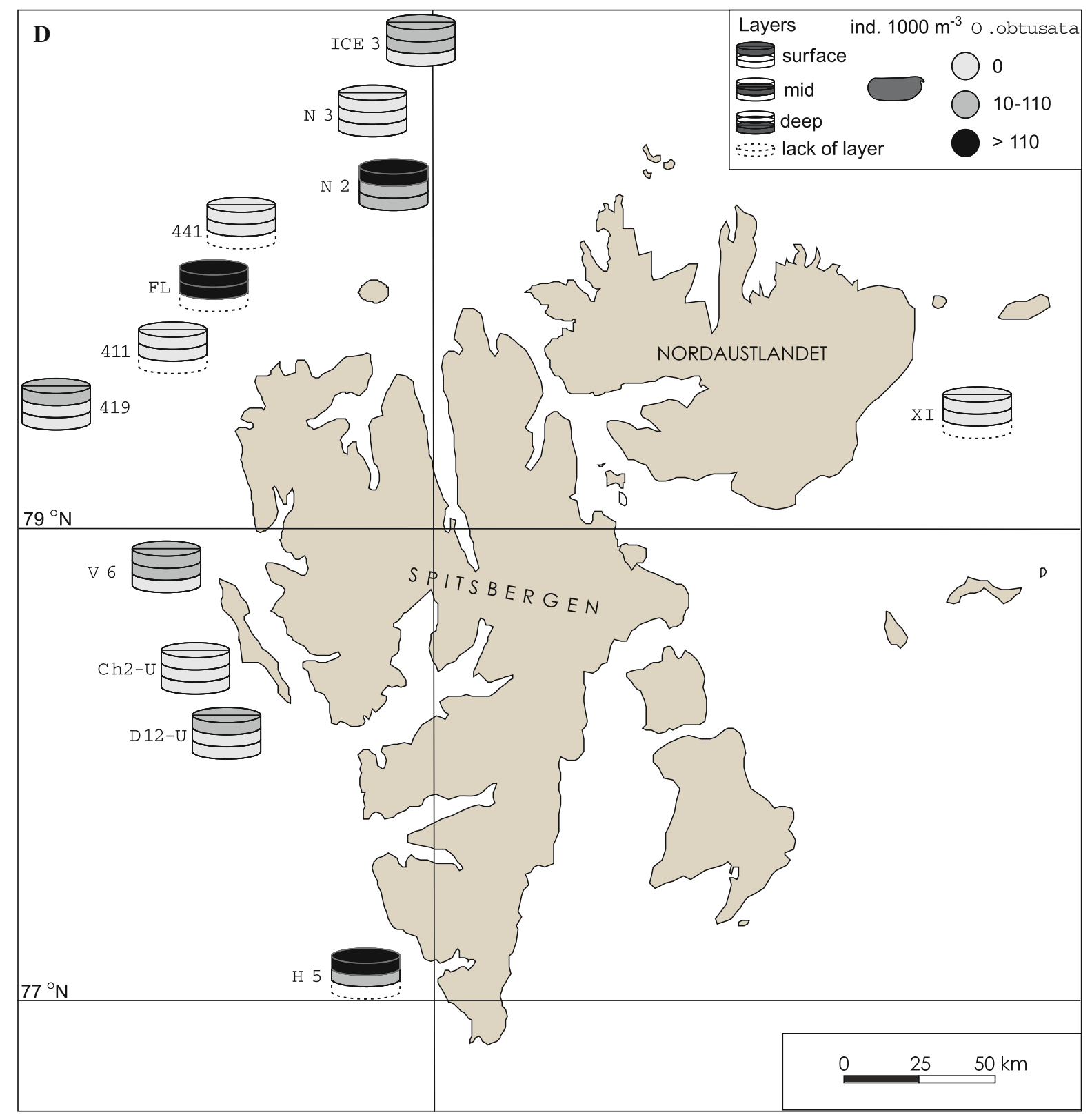

Fig. 4 continued

Atlantic at boreo-arctic latitudes (Angel \& Fasham, 1975; Poulsen, 1977; Bashmanov \& Chavtur, 2008). The previous confusions of this species with $B$. maxima make difficult the comparisons of our data with many of the earlier studies (Haberströh, 1985; Richter, 1994). The reasons for this confusion are in retrospect difficult to comprehend. Not only there are considerable differences in size between the two species, but the presence of sharply angled shoulder vaults in B. borealis - a characteristic that is shared with very few other halocyprids species (namely Paraconchoecia spinifera, Paraconchooecia dasyophthalma, Paraconchoecia mesadenia and Loricoecia acutimarginata) distinguishes both adults and the juveniles instars. Several investigations in North Atlantic, Greenland Sea and Nansen Basin (Wiborg, 


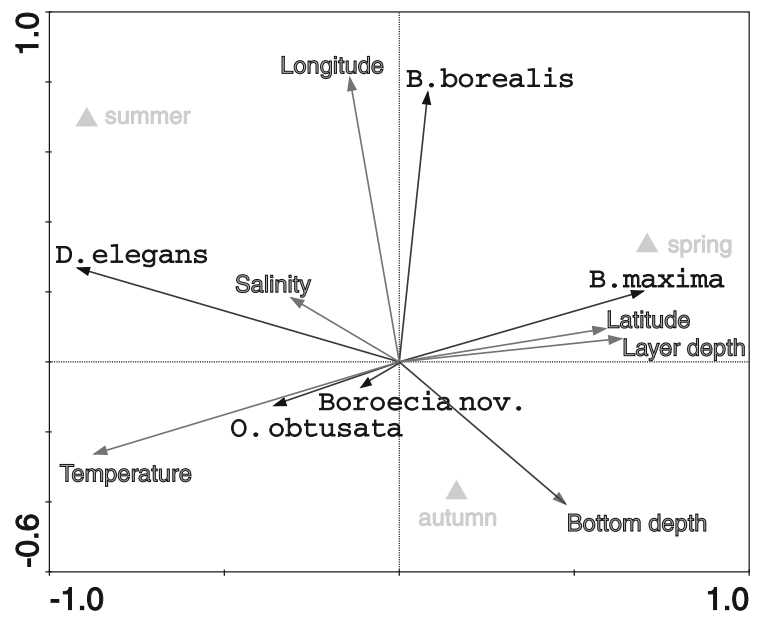

Fig. 5 Redundancy analysis (RDA) of Ostracoda abundances (ind. $1000 \mathrm{~m}^{-3}$ ) in Svalbard waters. Three depth categories were applied: surface $(0-200 \mathrm{~m})$, mid (200-bottom at shallow stations, and 200-600 $\mathrm{m}$ at deep stations) and deep (600bottom). The first canonical axis (RDA-1) explained $29.3 \%$ of the species-environmental relationship, and the second axis (RDA-2) explained $14.4 \%$

1955; Haberströh, 1985; Mumm, 1991, 1993; Richter, 1994) have reported B. borealis as playing a dominant role in the halocyprid assemblages contributing $60-80 \%$ of all the identified pelagic Ostracoda and up to $4-5 \%$ of the total mesozooplankton population. At two stations at $60^{\circ} \mathrm{N} 20^{\circ} \mathrm{W}$ and $53^{\circ} \mathrm{N} 20^{\circ} \mathrm{W}$ Angel \& Fasham (1975) reported that $B$. borealis was the dominant species at mesopelagic depths. As reported by Bashmanov \&

Table 3 Ranking of environmental variables in the Svalbard waters with a significant influence on pelagic Ostracoda distribution (Monte Carlo permutation test in RDA, $P<0.05$ ), with significant values in bold and remaining values with bordered significance

\begin{tabular}{lllr}
\hline Variable & $\begin{array}{l}\text { Explained } \\
\text { variability (\%) }\end{array}$ & $P$ & $F$ \\
\hline Temperature & $\mathbf{2 3}$ & $\mathbf{0 . 0 0 2}$ & $\mathbf{1 5 . 8}$ \\
Longitude & $\mathbf{1 2}$ & $\mathbf{0 . 0 0 2}$ & $\mathbf{8 . 8}$ \\
Latitude & $\mathbf{4}$ & $\mathbf{0 . 0 2 6}$ & $\mathbf{3 . 7}$ \\
Bottom depth & $\mathbf{4}$ & $\mathbf{0 . 0 3 8}$ & $\mathbf{3 . 3}$ \\
Spring & $\mathbf{3}$ & $\mathbf{0 . 0 5 4}$ & $\mathbf{2 . 8}$ \\
Autumn & $\mathbf{3}$ & $\mathbf{0 . 0 5 4}$ & $\mathbf{2 . 8}$ \\
Salinity & 2 & 0.144 & 1.6 \\
Layer depth & 1 & 0.354 & 1.1 \\
Summer & 1 & 0.738 & 0.4 \\
\hline
\end{tabular}

Chavtur $(2008,2009)$ the species is mainly limited to the boreal Atlantic, but there are several records of its extending as far south as $30^{\circ} \mathrm{N}$. It also occurs in sparse numbers in the deep water regions of the Arctic, particularly to the north of the Bering Strait and the Canadian Arctic coastline. There are a number of problems that need to be sorted out with the genus Boroecia. Poulsen (1973) who proposed the genus to accommodate some of the species that had been classified by Müller in his 'Mollicia' group of species in his all embracing concept of Conchoecia, failed to designate a type species and gave a very inadequate definition of the genus. Nowadays, few attempts to revise Boroecia genus have been carried out (Chavtur, unpubl. data, Angel \& Blachowiak-Samolyk in prep.), but they remain unfinished.

The smallest (o $1.58-1.86 \mathrm{~mm}$ and of 1.14 $1.30 \mathrm{~mm}$ ) species which ranked fourth in Ostracoda abundance in the waters around Svalbard was $O$. obtusata (4\%). This is one of the few halocyprid species that is associated with the upper water column. For example Williams (1975) commented that this species can contribute $79 \%$ of Ostracoda populations in lower latitudes of North Atlantic waters, however, his data came from the Continuous Plankton Recorder that is towed at depths of only about $8 \mathrm{~m}$, and so is unrepresentative of mesopelagic and bathypelagic assemblages. It is also another of the species reported by Sars (1865) from the Norwegian Sea, a well-known endemic to the boreal and temperate North Atlantic (Angel \& Fasham, 1975; Poulsen, 1977; Angel \& Blachowiak-Samolyk, 2006). Obtusoecia obtusata has been recently reported as occurring very infrequently quite far north in the Arctic by Russian researchers and contributed 4-20\% of pelagic Ostracoda, and even 50\% near Islands of Franz Josef Land. This suggests a close relationship between its abundance and the inflows of WSC into the Svalbard area.

Little can be said about the horizontal distribution of the novel species of Boroecia.

Analysis of the horizontal distribution of pelagic Ostracoda around Svalbard shows a rather uneven pattern, which may partly be a reflection of general zooplankton patchiness (e.g., Wiebe \& Holland, 1968). The lowest abundance of pelagic Ostracoda was recorded at the shallow Barents Sea station XI (bottom depth of $220 \mathrm{~m}$ ). Similarly, most of the stations situated over the continental slope of the Fram 
A

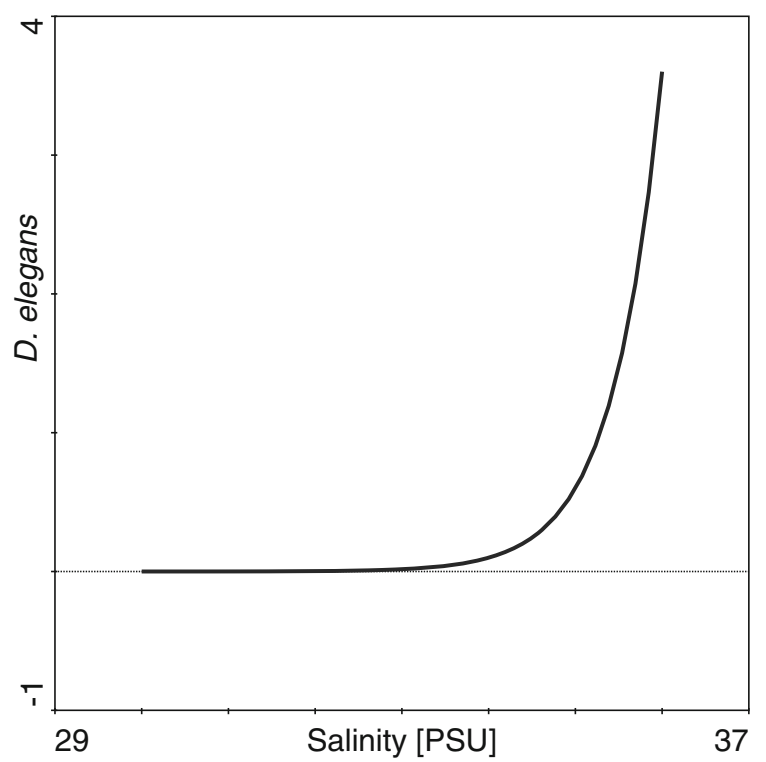

C

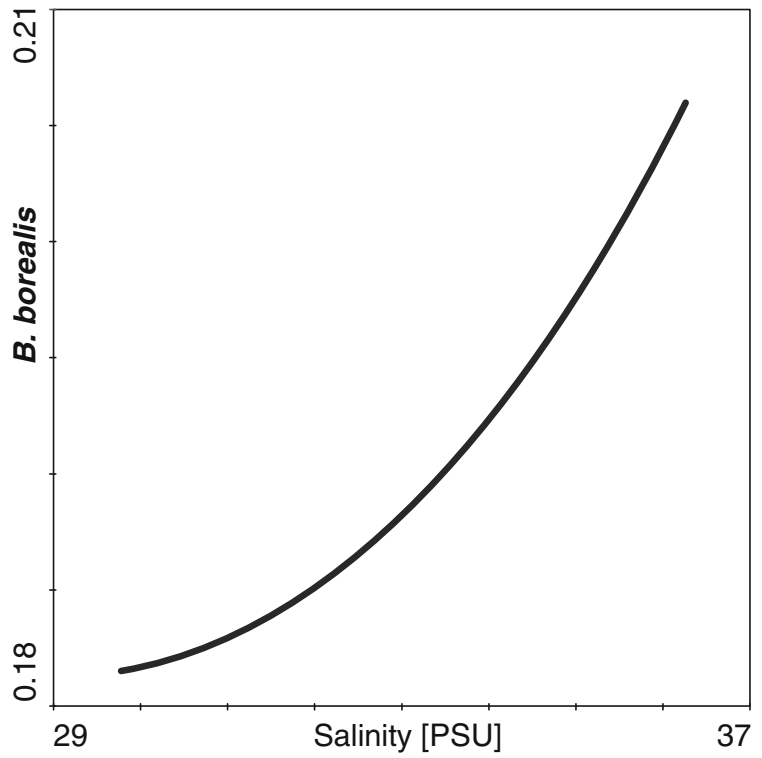

Fig. 6 Species Response Curves plotted against the variables with the strongest influence for their abundance $(P>0.05)$. A $D$. elegans plotted against salinity, B B. maxima plotted against

Strait were characterised by relatively low Ostracoda densities (Fig. 3). The highest concentration of pelagic Ostracoda in the current study was encountered at station 419, the most western locality sampled which agreed with Richter (1994) and WeigmannHaass (1997) observations that numbers of pelagic Ostracoda increases towards west in Greenland Sea.
B

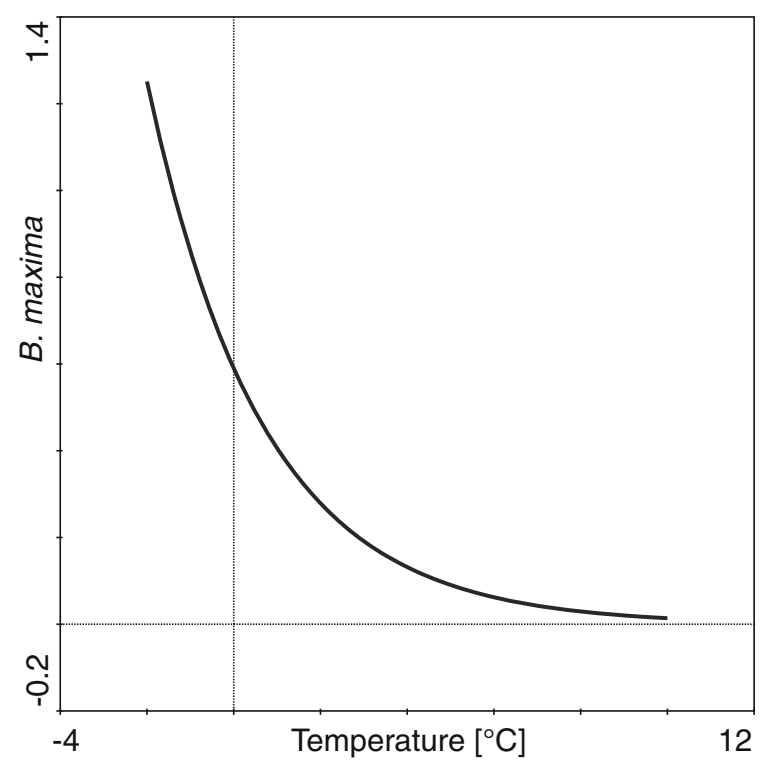

D

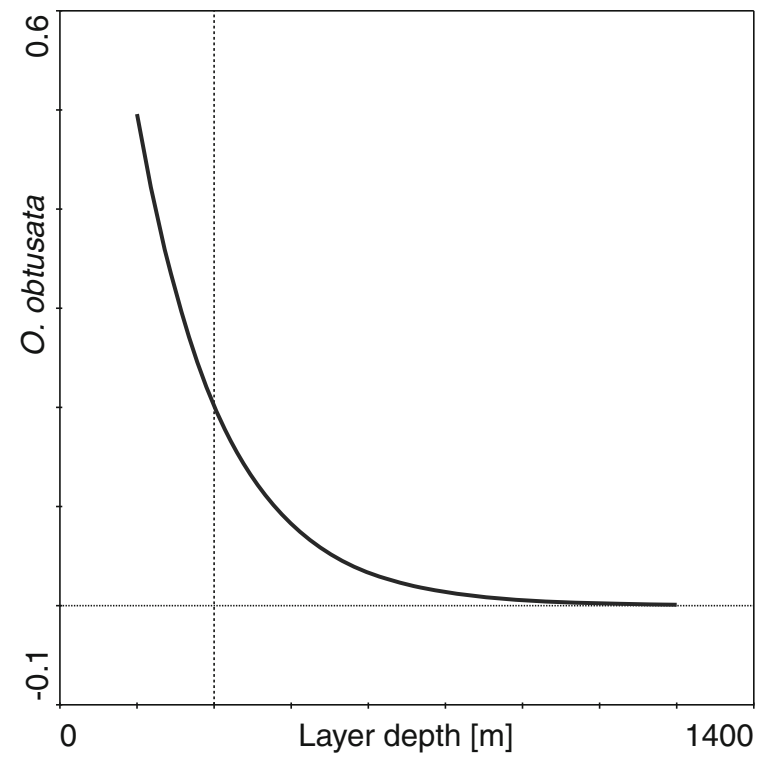

temperature, C B. borealis plotted against salinity, D O. obtusata plotted against layer depth

Bathymetric distribution

The vertical distributions of the pelagic Ostracoda showed some characteristic features. Discoconchoecia elegans has been recognised as being a mesopelagic species (Angel et al., 2007), and in the Svalbard samples it occurred in highest abundances in the mid- 
layer (Fig. 4A), which is in agreement with Poulsen's (1977) and Bashmanov \& Chavtur's (2009) data, but contrary to Mumm's (1991) results from the Nansen Basin, in which $D$. elegans was recorded as a surface layer inhabitant (with abundances up to 2500 ind. $1000 \mathrm{~m}^{-3}$ ). In the present material B. maxima was concentrated in the deep layer (below $600 \mathrm{~m}$ ) of Svalbard waters (Fig. 4B), which is in agreement with some previous results (Cleve, 1900; Stephensen, 1938; Grainger, 1965; Richter, 1994), but contrary to Bashmanov \& Chavtur's (2008) who report its highest concentration to be between $25 \mathrm{~m}$ and $100 \mathrm{~m}$ in the Central Arctic, but deeper (500-750 m) near Svalbard. Maximum densities of $B$. borealis were in the midlayer around Svalbard (Fig. 4C), which agrees with previously published data from high latitudes by Bashmanov \& Chavtur (2008). However, some authors (e.g., Mumm, 1991) have reported a maximum abundance of the species (7000 ind. $1000 \mathrm{~m}^{-3}$ ) at the shallower depth (between 100 and $200 \mathrm{~m}$ ).

Obtusoecia obtusata has been characterised as being a relatively shallow dwelling species (Grainger, 1965; Williams, 1975; Poulsen, 1977; Angel \& Blachowiak-Samolyk, 2006), and this was also confirmed by the present data (Fig. 4D).

Environmental influence on pelagic Ostracoda distribution

Apart from the results of Fasham \& Angel (1975) in which water mass are found to play an important role in the determining the distributions of halocyprid assemblages, little is known about how pelagic Ostracoda distributions are influenced by physical parameters. To obtain information on the quality and scale of the interactions between the various environmental factors and pelagic Ostracoda abundances (ind. $1000 \mathrm{~m}^{-3}$ ), a correspondence analysis were performed using RDA ordination model (CANO$\mathrm{CO})$. The factors like temperature, longitude, latitude, bottom depth, seasons (Spring, Summer and Autumn), salinity and layer depth together explained $53 \%$ of the total variability in Ostracoda distribution within the study area (Table 3). Blachowiak-Samolyk et al. (2008) and Søreide et al. (2003) observed similar impacts of various environmental variables on the total variability of zooplankton in Svalbard waters.
Temperature was the most important contributor to the RDA model (Fig. 5), explaining 23\% of the species variability (Table 3). Many authors (e.g., Søreide et al., 2003; Pedersen et al., 2005; Blachowiak-Samolyk et al., 2008) have also observed a close relationship between zooplankton distribution and temperature. The current study showed that $D$. elegans and O. obtusata were essentially the species whose higher abundances were evidently influenced by the stronger inflow of Atlantic Water into the Svalbard waters region (Fig. 5). Similar results were indicated previously for D. elegans by Wiborg (1955) and Richter (1994) as well as for O. obtusata by Angel \& Blachowiak-Samolyk (2006) and Bashmanov \& Chavtur (2009). The opposite relationship emerged in the present study for high Arctic species-B. maxima (Fig. 6B) was previously described by Grainger (1965) and Chavtur \& Bashmanov (2007, 2009). Thus it seems that halocyprids have the potential to be good indicators of environmental changes associated with shifts in climate and circulation patterns at high latitudes in the North Atlantic.

Longitude explained $12 \%$ of the whole Ostracoda variability described by RDA model presented in the current study. The close association between $B$. borealis densities and geographical position illustrated here is in agreement with the observed correlations in North Atlantic and Arctic waters (Bashmanov \& Chavtur, 2008). Latitude also proved to be a statistically significant variable with the highest concentrations of Arctic species-B. maxima being positively correlated with increase of latitude (Fig. 5), whereas the inverse pattern was observed for cosmopolitan $D$. elegans.

Stations' bottom depths can be another significant factor influencing pelagic Ostracoda distributions (Wiborg, 1955; Williams, 1975; Angel, 1977a, b; Richter, 1994; Blachowiak-Samolyk \& Angel, 2007; Bashmanov \& Chavtur, 2008) and this is confirmed to some degree by the present study. A previous zooplankton investigation (Blachowiak-Samolyk et al., 2008) showed that pelagic Ostracoda are highly correlated with bottom depth, but in the present study this factor explained only $4 \%$ of the whole halocyprid variability. The difference between these results was most probably a consequence of analysing the Ostracoda as a single relatively coherent group within the total zooplankton assemblage (Blachowiak-Samolyk et al., 2008) and the current study in which five species 
with different depth preferences have been taken into account. This relatively low impact of bottom depth may be also an artefact of the extensive depth ranges covered in our survey (from about $220 \mathrm{~m}$ in the Barents Sea to $1300 \mathrm{~m}$ in Fram Strait).

Before conducting the analyses season was expected to be one of the significant variables. Surprisingly Spring and Autumn each explained just $3 \%$ of the total Ostracoda variability around Svalbard (Table 3), and Summer did not significantly contribute to the RDA model (1\%). This difference may result from the disparity in the number of stations sampled in each season (for details see "Materials and methods" section), but more likely, explanation may lie in the diets of the Ostracoda. They are detritivores (Angel, 1983a, b; Kock, 1993), so they are much less dependent of the timing of Arctic phytoplankton bloom than herbivorous taxa.

Salinity contributed weakly (2\%) to the overall variability of the Ostracoda (Table 3). It did significantly influence the distributions of D. elegans and $B$. borealis when individual species were analysed (Fig. 6A, C). This result confirms either the earlier observations of Weigmann-Haass (1997) that increase in abundance of D. elegans is associated with salinities $>35$ PSU (Fig. 6A), or that the species is especially common in saline AtW (Wiborg, 1955; Richter, 1994; Bashmanov \& Chavtur, 2009).

Rather surprisingly this study showed that sampling depth was not a statistically significant variable in contrast to the results of Angel et al. (2007). A possible explanation could be that some of the species in our survey tend to be concentrated within relatively narrow depth ranges of the mesopelagial zone. It may also reflect a different way in which halocyprid and possibly zooplankton assemblages are organised bathymetrically at high latitudes compared to low latitudes.

\section{Conclusions}

In conducted studies $D$. elegans was the most abundant species, the other found species were: B. maxima, $B$. borealis, $O$. obtusata and a novel species that may be another Boroecia species.

Statistical analyses of the data showed that $53 \%$ of the variability of the pelagic Ostracoda assemblages was explained by environmental variables. The highest densities of $D$. elegans were correlated with high salinities, which can indicate high correlation with Atlantic inflow. Conversely the second most abundant deep water species B. maxima distribution was associated with the inflow of Arctic water into the region via the East Spitsbergen Current. Mid-layer species B. borealis and shallow living species $O$. obtusata were probably advected into the area via the inflows of Atlantic Water in West Spitsbergen Current.

Thus if global climate change results in any weakening of the inflow of Atlantic water into the region a decline in the contributions of D. elegans and $O$. obtusata can be expected, while that of B. maxima will be expected to increase. On the other hand, if the flow of Atlantic waters will increase, the opposite trends can be expected. Thus halocyprids have the potential to be good indicators of environmental changes associated with shifts in climate at high latitudes in the North Atlantic.

Acknowledgments We are grateful to the leaders of various cruises/projects: Stig Falk-Petersen (On Thin Ice), Paul Wassmann (CABANERA), Eva Leu (UV Project), Jan Marcin Weslawski (Svalbard fjord's programmes) and Slawomir Kwasniewski (AREX) for sharing zooplankton samples. Special thanks are due to Arild Sundfjord and Wojtek Walkusz for their help in completing both hydrological data and necessary literature. Primary funding for this study was provided by Arctic Ocean Biodiversity (ArcOD minigrant system), with additional support from Polish Ministry of Education and Science grant (419/N-PELOTA/2009/0) provided in close association with Census of Marine Zooplankton project.

Open Access This article is distributed under the terms of the Creative Commons Attribution Noncommercial License which permits any noncommercial use, distribution, and reproduction in any medium, provided the original author(s) and source are credited.

\section{References}

Angel, M. V., 1968. A study of planktonic Ostracods of the North Atlantic. Dissertation for the degree of Ph.D. in the University of Bristol.

Angel, M. V., 1977a. Windows into a sea of confusion: sampling limitations to the measurement of ecological parameters in oceanic mid-water environments. In Anderson, N. R. \& B. J. Zahuranec (eds), 1977: Oceanic Sound Scattering Prediction. Plenum Press, New York.

Angel, M. V., 1977b. Studies on Atlantic halocyprid ostracods: vertical distributions of the species in the top $1000 \mathrm{~m}$ in the 
vicinity of $44^{\circ} \mathrm{N}, 13^{\circ} \mathrm{W}$. Journal of the Marine Biological Association of the United Kingdom 57: 239-252.

Angel, M. V., 1983a. A vertical profile of planktonic ostracods at $42^{\circ} \mathrm{N}, 17^{\circ} \mathrm{W}$ from depths of $1500-3900 \mathrm{~m}$. In Maddocks, R. F. (ed.), Applications of Ostracoda. University of Houston Geoscience Department, Houston Texas: 549-559.

Angel, M. V., 1983b. A review of the progress of research on halocyprid and other oceanic planktonic ostracods 1972-1982. In Maddocks, R. F. (ed.), Applications of Ostracoda. University of Houston Geoscience Department, Houston Texas: 529-548.

Angel, M. V., 1993. Pelagic marine Ostracoda. Synopses of the British Fauna (New Series), D. M. Kermack, R. S. K. Barnes \& J. H. Crothers (eds), 48, published for Linnean Society of London and The Estuarine and Coastal Sciences Association by the Field Studies Council: 1-239.

Angel, M. V. \& K. Blachowiak-Samolyk, 2006. Obtusoecia (Halocyprida: Myodocopa: Ostracoda) a bipolar planktonic oceanic genus. Taxonomy, bathymetry and zoogeographical distribution. Annales Zoologici 56: 197-213.

Angel, M. V. \& M. J. R. Fasham, 1975. Analysis of the vertical and geographic distribution of the abundant species of planktonic Ostracods in the North-east Atlantic. Journal of the Marine Biological Association of the United Kingdom 55: 709-737.

Angel, M. V., K. Blachowiak-Samolyk, I. Drapun \& R. Castillo, 2007. Changes in the composition of planktonic ostracod populations across a range of latitudes in the North-east Atlantic. Progress in Oceangraphy 71: 60-78.

Bashmanov, A. F. \& V. G. Chavtur, 2008. Distribution of Boroecia borealis (Ostracods: Halocypridae) in the Arctic Ocean and adjacent waters of the Atlantic. Russian Journal of Marin Biology 34: 341-350.

Bashmanov, A. \& V. G. Chavtur, 2009. Structure and distribution of pelagic ostracods (Ostracoda: Myodocopa) in the Arctic Ocean. Russian Journal of Marine Biology 35: 359-373.

Blachowiak-Samolyk, K., 1999. Distribution and population structure of pelagic Ostracoda near the Antarctic Peninsular in spring 1986 BIOMASS III, October-November 1986. Polish Archives of Hydrobiology 46: 9-25.

Blachowiak-Samolyk, K. \& M. V. Angel, 2007. A year round comparative study on the population structures of pelagic Ostracoda in Admiralty Bay (Southern Ocean). Hydrobiologia 585: 67-77.

Blachowiak-Samolyk, K., S. Kwasniewski, H. Hop \& S. FalkPetersen, 2008. Magnitude of mesozooplankton variability: a case study from the Marginal Ice Zone of the Barents Sea in spring. Journal of Plankton Research 30: 311-323.

Braak, C. J. F. \& P. Smilauer, 2002. CANOCO Reference Manual and CanoDraw for Windows User's Guide: Software for Canonical Community Ordination (version 4.5). Microcomputer Power, Ithaca, NY (www.canoco.com).

Brady, G. S. \& A. M. Norman, 1896. A monograph of the marine and freshwater ostracoda of the North Atlantic and of northwestern Europe. Section II: Myodopoda, Cladopoda and Platycopa. Scientific Transactions of the Royal Dublin Society 5: 621-784.

Chavtur, V. G., 1977. Fauna of pelagic Ostracods of the Halocypridae family in the northwestern part of the Pacific Ocean. Biologya Morya 1: 28-38.
Chavtur, V. G. \& A. G. Bashmanov, 2007. Distribution and seasonal dynamics of Boroecia maxima (Ostracoda: Halocypridinae) in the Arctic basin and adjacent Atlantic waters. Russian Journal of Marine Biology 33: 75-83.

Claus, C., 1890. Die Gattungen und Arten der mediterranen und atlantischen Halocypriden nebst Bemerkungen über die Organisation derselben. Arbeiten aus dem Zoologischen Institute der Unversität Wien 9: 1-34.

Cleve, P. T., 1900. The seasonal distribution of Atlantic plankton organisms, Göteborg, 1900.

Cottier, F., V. Tverberg, M. Inall, H. Svendsen, F. Nilsen \& C. Griffiths, 2005. Water mass modification in an Arctic fjord through cross-shelf exchange: the seasonal hydrography of Kongsfjorden, Svalbard. Journal of Geophysical Research 110: 1-18.

Deevey, G. B., 1968. Pelagic Ostracods of the Sargasso Sea off Bermuda: description of species and seasonal and vertical distribution. Bulletin of the Peabody Museum of Natural History 26: 1-125.

Fasham, M. J. R. \& M. V. Angel, 1975. The relationship of the zoogeographic distributions of the planktonic Ostracods in the North-east Atlantic to the water masses. Journal of the Marine Biological Association of the United Kingdom 55: 739-757.

Grainger, E. H., 1965. Zooplankton from the Arctic Ocean and adjacent Canadian waters. Journal of the Fisheries Research Board of Canada 22: 546-560.

Haberströh, D., 1985. Die Vertikalverteilung von planktonischen Crustaceen auf einem Schnitt in der nördlichen Framstrasse. Diploma Thesis, Würzburg University, 140.

Hanssen, H., 1997. Mesozooplankton of the Laptev Sea and the adjacent eastern Nansen Basin-distribution and community structure in late summer. Reports on Polar Research. Alfred Wegener Institute for Polar and Marine Research 229: 131 pp.

Hirche, H. J., M. E. M. Baumann, G. Kattner \& R. Gradinger, 1991. Plankton distribution and the impact of copepod grazing on primary production in Fram Strait, Greenland Sea. Journal of Marine Systems 2: 477-494.

Iles, E. J., 1953. A preliminary report on the Ostracoda of the Benguela Current. Discovery Report 26: 259-280.

Kielhorn, W. V., 1952. The biology of the surface zone zooplankton of a boreo-arctic Atlantic Ocean area. Journal of the Fisheries Research Board of Canada 9: 223-264.

Kock, R., 1993. Planktonic Ostracods along the Antarctic Peninsula during the 1989/90 summer season. Polar Biology 13: 495-499.

Koppelmann, R. \& H. Weikert, 1999. Temporal changes of deep-sea mesozooplankton abundance in the temperate NE Atlantic and estimates of the carbon budget. Marine Ecology Progress Series 179: 7-40.

Kosobokova, K. N., 1982. Composition and distribution of the biomass of zooplankton in the central Arctic Basin. Oceanology 22: 744-750.

Kosobokova, K. \& H. J. Hirche, 2000. Zooplankton distribution across the Lomonosov Ridge, Arctic Ocean: species inventory, biomass and vertical structure. Deep-Sea Research Part I 47: 2029-2060.

Kosobokova, K. N. \& R. R. Hopcroft, 2010. Diversity and vertical distribution of mesozooplankton in the Arctic's Canada Basin. Deep-Sea Research Part II 57: 96-110. 
Loeng, H., 1991. Features of the physical oceanographic conditions of the Barents Sea. Polar Research 10: 5-18.

Martens, J. M., 1979. Die pelagischen Ostracoden der Expedition Marchile I (Südost- Pazifik) II: Systematik und Vorkommen (Crustacea: Ostracoda: Myodocopa). Mitteilungen Hamburg Museum und Institut 76: 303-366.

Müller, G. W., 1906. Ostracoda. In Wissenschaftliche Ergebnisse der Deutschen Tiefsee-Expedition 'Valdivia' 1989-1899, Vol. 8: 29-154.

Mumm, N., 1991. On the summer distribution of mesozooplankton in the Nansen Basin, Arctic Ocean. Berichte fur Polarforschung 92: 1-146.

Mumm, N., 1993. Composition and distribution of mesozooplankton in the Nansen Basin, Arctic Ocean, during summer. Polar Biology 13: 451-461.

Pedersen, S. A., M. H. Ribergaard \& C. S. Simonsen, 2005. Micro- and mesozooplankton in Southwest Greenland waters in relation to environmental factors. Journal of Marine Systems 56: 85-112.

Piechura, J., A. Beszcznska-Moeller \& R. Osinski, 2001. Volume, heat and salt transport by the West Spitsbergen Current. Polar Research 20: 233-240.

Poulsen, E. M., 1973. Ostracoda-Myodocopa. Part 3: B. Halocypriformes-Halocypridae, Conchoecinae. Dana Report 84: 1-224.

Poulsen, E. M., 1977. Zoogeographical remarks on marine pelagic Ostracoda. Dana Report 87: 1-33.

Richter, C., 1994. Regional and seasonal variability in the vertical distribution of mesozooplankton in the Greenland Sea. Berichte zur Polarforschung 154: 1-87.

Sars, G. O., 1865. Oversigt of Norges marine Ostracoder. Forhandlinger i Videnskab—Selskabet i Christiana 17: 1-130.
Skogsberg, T., 1920. Studies on marine ostracods. Pt. 1 (Cypridinids, Halocypridinids and Polycopids). Zoologiska Bidrag från Uppsala 1: 1-784.

Søreide, J. E., H. Hop, S. Falk-Petersen, B. Gulliksen \& E. Hansen, 2003. Macrozooplankton communities and environmental variables in the Barents Sea marginal ice zone in late winter and spring. Marine Ecology Progress Series 263: 43-64.

Stephensen, K., 1938. Marine Ostracoda and Cladocera. The Zoology of Iceland 3: 1-19.

Svendsen, H., H. Svendsen, A. Beszczynska-Møller, J. O. Hagen, B. Lefauconier, V. Tverberg, S. Gerland, J. B. Ørbøk, K. Bischof, C. Papucci, M. Zajaczkowski, R. Azzolini, O. Bruland, C. Wiencke, J. G. Winther \& W. Dallmann, 2002. The physical environment of Kongsfjorden-Krossfjorden, an Arctic fjord system in Svalbard. Polar Research 21: 133-166.

Weigmann-Haass, R., 1997. The distribution of macrozooplankton in the Greenland Sea in late autumn 1988 (Crustacea: Ostracoda, Hyperiidea [Amphipoda], Euphausiacea). Helgolander Meeresuntersuchungen 51: 69-82.

Wiborg, K. F., 1955. Zooplankton in relation to hydrography in the Norwegian Sea. Fiskeridirektoratets Skrifter Serie Havundersøkelser 11: 1-66.

Wiebe, P. H. \& W. R. Holland, 1968. Plankton patchiness: effects on repeated net tows. Limnology and Oceanography 13: 315-321.

Williams, R., 1975. Continuous plankton records: a plankton atlas of the North Atlantic and North Sea. Supplement 4: The Ostracoda in 1963. Bulletin of Marine Ecology 8: 215-228. 